\title{
Eurípedes Simões de Paula
}

\section{OSWALDO PEREIRA PORCHAT}

$\mathrm{N}$ ão é difícil escrever um depoimento sobre alguém que, durante anos a fio, aprendemos a respeitar, admirar e estimar. Por isso, não me é diff́cil escrever este depoimento sobre Eurípedes Simões de Paula. Aliás não fui apenas seu amigo; eu tinha por ele algo como uma estima filial. E estou muito seguro de que tais sentimentos encontravam, de sua parte, acolhida e correspondência.

Eurípedes Simōes de Paula tinha seus defeitos. Quem não os tem? Mas ele nấo os escondia nem dissimulava. Nem poderia fazê-lo, se o quisesse. Ele exibia seus sentimentos à luz do dia, revelava-se inteiro no que dizia e no que silenciava. Faltava-lhe o dom da hipocrisia... Năo se trata aqui de glorificá-lo, de hiperdimensionar seus feitos ou suas qualidades. Nem de minimizar falhas. Sua memória náo precisa de nossa complacência, nem de nossa generosidade. Basta-lhe a verdade daquele Eurípedes real e humano.

Foi sobretudo como administrador, todos o sabem, que Eurípedes Simóes de Paula se realizou. Como diretor da Faculdade de Filosofia, durante tantas e tantas gestóes. Foi no dia-a-dia de sua atividade incansável de diretor que ele nos revelou aquelas qualidades que o tornaram inesquecível: sua enorme bondade, sua generosidade inigualável, sua afetividade saudável, sua simplicidade tranqüila. Ao lado de uma operosidade invejável, um idealismo imbatível, uma paixão profunda e obsessiva pela instituição que dirigia. A Faculdade de Filosofia era, de fato, sua grande paixão. Dela falava de boca cheia. Sonhava em fazê-la ainda melhor e maior.

E trabalhava infatigavelmente para que o sonho se tornasse realidade. Sua presença inarredável conferia continuamente à Escola vida e dinamismo. Incentivava estudos, pesquisas, publicaçóes. Animava e protegia quem se mostrasse disposto a trabalhar. Acolhia idéias com entusiasmo.

Tinha uma capacidade desconcertante para contornar situaçóes dificeis e quase sempre se saía bem. Isso permitiu-lhe, em muitos momentos de crise, preservar melhor a Faculdade. Nos conflitos e disputas, procurava conscientemente fazer média, atender a ambos os lados. Náo era homem de opções radicais. Nas situaçóes institucionais, estava sem- 
pre atento ao lado humano dos problemas. Aborrecia-o a retórica oficial ociosa e obsoleta. Procurava ir direto ao verdadeiro âmago das questóes e ver as coisas com simplicidade.

Permitia-se explosóes verbais em seus rompantes, mas nảo guardava rancor ou ressentimento. Quando alvo de críticas que lhe pareciam injustas, opunha-lhes seu espírito de compreensáo e uma tranquiila superioridade.

A porta do seu gabinete permanecia literalmente aberta a professores, estudantes e funcionários. Bom e magnânimo, era o pai comum a quem todos recorriam para resolver questōes administrativas ou problemas pessoais. Detestava dizer não. Os estudantes mereciam dele um carinho todo especial. Seu paternalismo sincero e afetuoso desarmava os mais renitentes.

Jamais aplicou a ferro e fogo as disposiçóes legais ou estatuárias. Tinha consciência de quáo injusta pode ser a fria aplicaçăo dos preceitos da lei. Ele sabia como driblar a sua rigidez. Também detestava punir. As puniçóes inadiáveis, sabia transformá-las em conversas de amigável advertência. Muitos abusaram - e muito - de sua generosidade. $\mathrm{E}$ isso não lhe escapava, no mais das vezes. Mas tinha feito, desde sempre, sua opçáo: confiar no ser humano, até prova irrefutável em contrário. E todos sabemos que tais provas dificilmente se produzem.

Eurípedes foi a alma da velha Maria Antônia. E ele viveu nela e com ela, alegrou-se com suas alegrias, sofreu com seus sofrimentos e jamais se conformou com o seu fim. Nos fins de 68, quando os fascistas a bombardearam horas a fio com coquetéis Molotov, atiraram sobre seus estudantes, matando um deles, ferindo outro, eu vi Eurípedes percorrer desolado, pátios e corredores, confortando os alunos atemorizados, expondo-se corajosamente nos lugares abertos. Afinal ele era sempre o capitáo da FEB, que combatera o fascismo nos campos de batalha da Itália e não se cansava de dizer seu orgulho por ter servido seu país como soldado.

Naquele momento duro e triste, eu vi Eurípedes desesperar-se ante a passividade escandalosa do contingente policial, que assistia à destruição da velha Escola e alegava ordens superiores para náo intervir. A ditadura não mais podia tolerar que, no coração da cidade de Săo Paulo, permanecesse aceso um foco de pensamento livre. Atônito e impotente, o diretor assistiu à agonia de sua Escola.

A Faculdade de Filosofia foi transferida (ou desterrada?) para a Cidade Universitária. Foi desmembrada em vários Institutos, com a 
Reforma Universitária. De um certo modo mais identificada com a vetha Maria Antônia, instalou-se a nova Faculdade de Filosofia, Letras e Ciências Humanas, que Eurípedes dirigiria por muitos anos. $O$ espírito da Maria Antônia, nele encarnado, ainda sobrevivia. Com a morte trágica de Eurípedes, encerrou-se uma fase de nossa vida universitária. Foi a agonia da Maria Antônia que chegou ao fim.

Vale a pena insistir um pouco sobre esse amor apaixonado de Eurípedes por sua Faculdade. Pois era algo de muito incomum. As instituiçōes universitárias continuam produzindo pesquisadores capazes $\mathrm{e}$

Euripedes Simóes de Paula

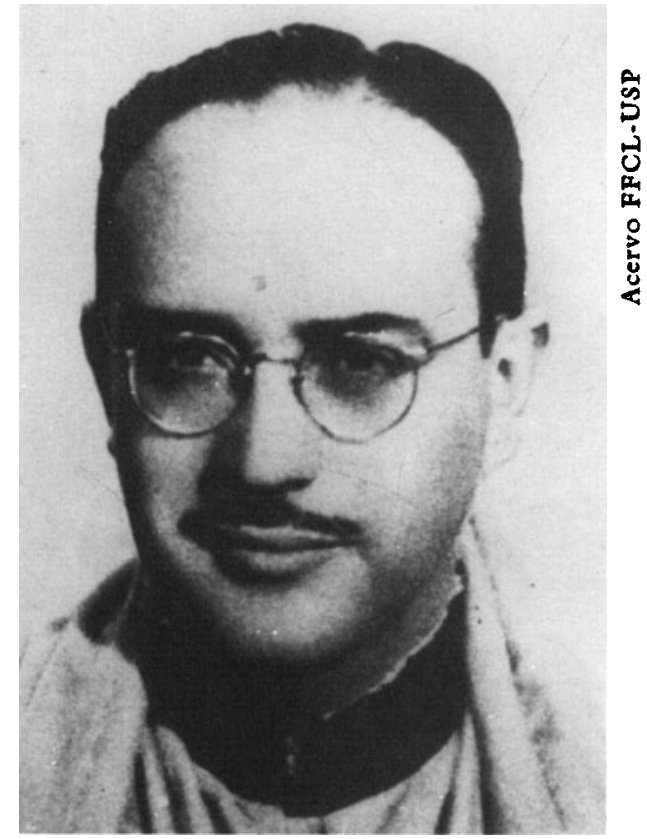

criativos, docentes dedicados, ainda que năo constituam, por certo, a maioria. Mas são bem pouco numerosos, infelizmente, os que nutrem um amor verdadeiro pela Instituiçăo. Os que se identificam realmente com ela e sonham em fazê-la crescer sempre mais, progredir, tornar-se forte. Que aceitam sacrificar-se por ela e buscam a ela servir, ao invés de servir-se dela. Eurípedes foi um desses poucos.

Seu exemplo foi um ensinamento constante, sua morte é um apelo a que o imitemos. Quantos o imitaráo?

Maria Regina, sua companheira inconsolável e guardiã carinhosa de sua memória, perguntou-me se eu escreveria um depoimento sobre 
Eurípedes. É com um prazer imenso que o faço. Também com uma enorme saudade e um sentimento de profunda gratidáos. Por tudo que ele fez por todos nós. Por tudo que ele fez pela Universidade.

Oswaldo Pereira Porchat é professor do Centro de Lógica, Epistemologia e História da Ciéncia da Unicamp.

Texto extraído de In Memoriam, Eumpedes Simóes de Paula (FFLCH-USP, 1993). 